p-ISSN: 2308-4944 (print) e-ISSN: 2409-0085 (online)

Year: 2017 Issue: $01 \quad$ Volume: 45

Published: $30.01 .2017 \quad$ http://T-Science.org

SECTION 24. Sociological research

\title{
YOUTH POLICY: PRIORITIES OF CONTEMPORARY CIVIL SOCIETY DEVELOPMENT
}

\author{
Abstract: Some aspects of development of youth policy in the Republic of Uzbekistan and processes of \\ perfection of civil society institutions in our country are considered. \\ Key words: youth, youth policy, Kamolot Youth movement of Uzbekistan, civil society, youth programs. \\ Language: English \\ Citation: Subhanov N (2017) YOUTH POLICY: PRIORITIES OF CONTEMPORARY CIVIL SOCIETY \\ DEVELOPMENT. ISJ Theoretical \& Applied Science, 01 (45): 176-178. \\ Soi: http://s-o-i.org/1.1/TAS-01-45-33 Doi: crossef https://dx.doi.org/10.15863/TAS.2017.01.45.33
}

\section{Introduction}

The present stage of social progress in Uzbekistan witnesses an unprecedented rise of the role of young generation in all spheres of social life: economics, politics, spiritual. Similarly, there has been a complete change in ideological orientation during the same period. Values previously viewed as lofty ideals and proved to be quite the reverse. In addition, the task of changing people's minds turned out to be the most difficult one.

In the international arena, the young people are becoming the influential force. In fact, the social activity of young people drives to the social progress. Actually, the formation of law-governed state itself requires kind of legislative and judiciary acts necessary for the comprehensive development of young people for identifying their social and political status as well as to work out efficient methods and means for their economic, judicial and social protection and ensuring their free development, establishment and promotion.

The youth policy in the Republic of Uzbekistan is based on the Constitution as well as on the mentioned Law and other legislative acts that regulate social, economic and other aspects concerning the interests of young people. This includes the Laws "On basics of state youth policy", "On preventing the neglect of under aged children", "On the state protection of child rights", Decrees of the $1^{\text {st }}$ President of the Republic of Uzbekistan "On state support of creative youth of Uzbekistan", "On promoting the efficiency of "Kamolot" Youth movement of Uzbekistan" [2], the Resolution of the
The state priority in the youth policy of the Republic of Uzbekistan is aimed the creating of social and economic, legislative and organizational conditions necessary for ensuring social establishment and development of young people and stimulating their creative potential in the interests of the whole society.

To this effect, the adoption of the Law "On basics of state youth policy of the Republic of Uzbekistan" [1] should be noted as an important event. By this Law, the state exercises the policy of creating conditions necessary for the social and spiritual development of young people. This policy provides the young people with the right of creating and establishing their judicially independent sociopolitical structures such as associations, foundations and movements.

\section{Materials and Methods}

Cabinet of Ministers of Uzbekistan "On the support of "Kamolot" youth movement of Uzbekistan", the Resolution of the President of the Republic of Uzbekistan "On additional measures on implementing the youth policy in the Republic of Uzbekistan" and other acts [3].

The main goal of the elaboration and implementation of the state youth program is the provision of conditions ensuring social support of youth, protection of their dignity, and specific economic, political, socio-cultural interests, and the support of their employment based on free choice. 
By the national legislation, young citizens of the Republic of Uzbekistan enjoy with a wide range of socio-economic, political and individual rights and liberties declared in the Constitution and in other legal acts. Any form of direct or indirect restriction of legitimate rights and interests of young people due to their age are not allowed and are punishable under the existing legislation.

The national legislation of the Republic of Uzbekistan also regulates the issues concerning the competence of under aged, rights of certain categories of young citizens (disabled persons, householders, adoptees of orphanages and others)

The social protection of young people includes a set of state guarantees offered to young citizens and their families for their physical, intellectual and spiritual development and social behavior in the interests of the population.

Special measures of social protection of under aged categories of young citizens (disabled persons, householders, adoptees of orphanages, pupils, students, discharged army servicemen and military reservists) as well as implementation of their rights are stipulated by the national legislation of the Republic of Uzbekistan.

In order to assist of young families and in line with the Law "On basics of state youth policy in the Republic of Uzbekistan" and the National program "The year of social protection" and also to expand the material and moral support for young families, their primary employment, and their adoption to the independent life path, formation of skills for stable earnings and also to improve their living conditions, the $1^{\text {st }}$ President of Uzbekistan the Decree "On additional measures of material and moral support of young families" on 18 May 2007 had issued.

Moreover, there are a number of national programs aimed at bringing up well-educated and healthy young generation by state bodies and institutions of civil society in order to implement the state youth policy successfully. The state programs such as "The year of young people", "The year of perfect generation", "The year of healthy child" are remarkable examples to this respect.

The state provides special support for the talented young people by financing measures to this effect from the central and local budgets, public funds and other sources.

At present time our society faces the task of working out factors necessary for the gradual integration of young people with the progress and first of all, for the formation of young generation capable of self-development and high degree of readiness for implementation of social functions.

The political activeness of young people is usually observed in political activity, communication, social behavior, and can be directed either at constructional and reformative changes of social relations or at destruction of out-of-date social formations. At the same time, personal activity is observed in the dally activity that draws the individual into political process that concerns its basic interests and values.

In the present-day Uzbekistan, the tasks of modernization and democratization, and the formation of civilian society are resolved step by step and consistently.

There is a clear public understanding of the importance of political parties as the most important apparatus of raising political activeness of citizens, expressing their will and views especially on electoral procedures and also in their direct part in forming state power bodies, both central and local.

It is impossible to overestimate the role and importance of political parties in strengthening democratic values in the minds of young people, in boosting their political and civilian activeness, along with broadening and deepening scales of democratic reforms in the country.

The young people in modern Uzbekistan belong to "the generation of transitional period", they advance towards the free democratic society and along this road, witness epochal changes. They experience effects of recent reforms on their own fate and understand hardships and problems of the transitional period.

Young people have specific place in the country's political and public life, in strengthening democracy, in forming civil society. The upcoming generation is presented with maximum opportunities to locate their place in the social life, make their fortune and choose ways of creativity.

Formation of new understanding by the young generation is a gradual and evolutionary process. Similarly, in the epoch of growing national selfidentity, in the process of bringing up well educated citizens of new generation, the basic values nevertheless remain as before - spirituality, morality and education. The Uzbek society, remaining as a part of oriental civilizations, at the same time also relies on experience and wisdom of its past generations.

Present-day Uzbek youth, who have a fortune to live in the epoch of grand changes, understands in full their responsibility for tasks facing them and first of all, the task of finding their place in the modern society.

Young people aged between 14 and 30 are more than 10 million of our country's population. This is evidence of the fact that young people are present practically in all spheres of the life. They are actively involved in the reforms; enrich themselves by the knowledge and wisdom of elder generations and by observing the experience of contemporary youth in developed countries.

It is beyond any doubt that the young generation, taking most active part in the country's social daily routine, contributes in further 


\begin{tabular}{|c|c|c|c|c|c|c|}
\hline Impact Factor: & $\begin{array}{l}\text { ISRA (India) } \\
\text { ISI (Dubai, UAE } \\
\text { GIF (Australia) } \\
\text { JIF }\end{array}$ & $\begin{array}{l}=1.344 \\
=0.829 \\
=0.564 \\
=1.500\end{array}$ & $\begin{array}{l}\text { SIS (USA) } \\
\text { PИНЦ (Russia) } \\
\text { ESJI (KZ) } \\
\text { SJIF (Morocco) }\end{array}$ & $\begin{array}{l}=0.912 \\
=0.234 \\
=1.042 \\
=2.031\end{array}$ & $\begin{array}{l}\text { ICV (Poland) } \\
\text { PIF (India) } \\
\text { IBI (India) }\end{array}$ & $\begin{array}{l}=6.630 \\
=1.940 \\
=4.260\end{array}$ \\
\hline
\end{tabular}

strengthening inter-ethnic accord and friendship, public thus ensuring peace, tranquillity and creative labour in our society.

\section{Conclusion}

Present-day youth in Uzbekistan are citizens of free and independent society, and they enjoy all rights and themselves make own choice. On the other hand, factors such as economic progress and developed civilian society create basis for even more efficient youth policy.

The primary goal pursued by this policy is the recognition of the young people as a category of population with their specific potentials and requirements.
The second goal of this policy is the adoption of programs concerning the interests of young people in learning vital skills, establishment of services in the interests of young people such as primary work employment, professional education of those engaged in the state-run sector as well as small and medium business, and also programs directed at strengthening civic values and education in citizenship responsibility skills.

The young people in Uzbekistan play an important role in the ongoing democratic processes and in formation of civil society, because only those who physically and spiritually are perfect and socially mobile are able to ensure the permanent progress of nation.

\section{References:}

1. (1991) Law of the Republic of Uzbekistan "On basics of the national youth policy" dated 20 November 1991. No 429-XII Available: www.lex.uz (Accessed: 10.01.2017).

2. (2001) Decrees by the President of the Republic of Uzbekistan "On Kamolot Youth foundation of the Republic of Uzbekistan" and "On raising the efficiency of the activity of Kamolot youth social movement"; resolution of the Cabinet of Ministers of Uzbekistan "On providing support in organization of the activity of Kamolot Youth social movement of Uzbekistan" dated 10 May 2001.

3. (2014) Resolution by the President of Uzbekistan dated 6 February 2014 PP-2124 "On additional measures for the implementing the National youth policy in the Republic of Uzbekistan"

4. (2010) Law of the Republic of Uzbekistan "On preventing the neglect and law-breaches among under aged" dated 29 September 2010 No ZRU-263 Available: www.lex.uz (Accessed: 10.01.2017).
5. (2008) Law of the Republic of Uzbekistan "On guarantees of child rights" dated 7 January 2008 No 139 ZRU Available: www.lex.uz (Accessed: 10.01.2017).

6. (1992) Decree by the president of Uzbekistan "On the state support of creative youth of Uzbekistan" dated 8 August 1992.

7. (2007) Decree by the President of Uzbekistan "On additional measures of material and moral support of young families" (Narodnoye Slovo daily; 19 May 2007)

8. (2008) Resolution by the Cabinet of Ministers of Uzbekistan dated 25 February 2008, PP-805 "On the National programme "The Year of youth".

9. (2010) Resolution of the Cabinet of Ministers of Uzbekistan dated 27 January 2010 PP-1271 "On the National programme "The Year of perfect generation"

10. (2014) Resolution of the Cabinet of Ministers of Uzbekistan dated 19 February 2014 PP-2133 "On the National programme "The Year of healthy child" 